UDK: 82 Isaković A.[82-21+808.61/.62(497.15)-3

Izvorni naučni rad

Primljeno: 13. 9. 2019.

Prihvaćeno za štampu: 13. 1. 2020.

dr. sci. Remzija Hadžiefendić-Parić, redovni profesor

Univerzitet u Bihaću

Islamski pedagoški fakultet

E-mail:remzija.badriefendic.pari@@zg.t-com.br

\title{
ISAKOVIĆEVA DRAMA „HASANAGINICA“ I NJEGOV „RJEČNIK KARAKTERISTIČNE LEKSIKE U BOSANSKOME JEZIKU“"
}

Trebalo bi se konačno sastati sa već davno odbjeglim srcem (M. Dizdar)

\section{Sažetak:}

U radu je fokus na leksičkom sastavu Isakovićeve drame Hasanaginica $(1982)^{1}$ s obzirom na postupke izdvajanja i tumačenje leksike $e^{2}$ u njegovom Rječniku karakteristične leksike u bosanskome jeziku (1991). Cilj je utvrditi odnos rijeci $u$ drami Hasanaginica i leksema ${ }^{3}$ uvrštenih u Rječnik - s polaznom pretpostavkom da postoji odredena podudarnost u njihovom izboru, formi i značenju, pri čemu se ne gubi iz vida da su u pitanju dva posve razlicita tipa tekstova, vrsno $i$ žanrovski, dva stila - književnoumjetnički (drama, tragedija) i primijenjeno naučni (rječnik, jednojezički), ${ }^{4}$ što za sobom

\footnotetext{
${ }^{1}$ Godina nav. prema bibliografiji M. Ćemana, v.: Alija Isaković, Taj čovjek, Pobuna materije, Svjetlost, Sarajevo, 1991: 366).

${ }^{2}$ Pod leksemom razumijeva se svaka jedinica koja se može naći u poziciji natuknice (riječ ili višečlani izraz, fraza).

${ }^{3}$ Čini se da je Isaković napravio ne samo stilski motiviranu, već i teorijski, razliku između termina riječ i leksema: jedno je jedinica realizacije ('jezika kao standarda'), a drugo (leksema) virtualna jedinica paradigmatske ose, tj. 'jezika kao sistema' (o čemu u kroatistici prvi piše prof. J. Silić, v. Kapetanović 2005).

${ }^{4} \mathrm{O}$ tome sam govorila na Naučnoj konferenciji Alija Isaković i bosanski jezik (14. marta 2017, Sarajevo) u radu Citati i fragmenti iz govora i jezika (Isakovićev Rječnik karakteristične leksike u bosanskome jeziku, balada Hasanaginica i istoimena
} 
povlači niz bitnih, medusobno suprotstavljenih distinkcija na planu leksike i njenog funkcioniranja u tekstu premda su i jedno i drugo, drama i rječnik, 'jeziku metajezici' (usp. Peti, 1995: 103), jedno in preasentia (drama), drugo in absentia (rječnik). U analizi se dakle polazi od toga da dramu i rječnik čine komponente različite strukturno (s obzirom na mjesto u tekstu), formalno (s obzirom na način pisanja), funkcionalno (s obzirom na uloge $u$ 'drugostepenom modelativnom sistemu' $i$ u leksikografskom djelu) $i$ jezičkostilski (s obzirom na vrijednosti i efekte). Koliko mi je poznato, za ovu temu do sada nije bilo naučnih zanimanja niti je bilo istraživanja o njoj. ${ }^{5} \mathrm{U}$ radu sam se zadržala samo na odredenim riječima iz drame preko kojih se mogu pratiti i u konačnici prepoznati bitne konture odnosa drame i Rječnika sa aspekta koji je odabran u ovom radu.

Ključne riječi: balada, Hasanaginica, drama, rječnik, Alija Isaković, bosanski jezik, bosnistika.

\section{RIJEČ PRIJE}

Baviti se dramom u Shakespeareovoj tek minuloj godini posve je obično, a uz stotu godišnjicu rođenja velikog bosanskohercegovačkog

Isakovićeva drama). Rad će biti objavljen u Zb. radova, izdavač je Institut za jezik, Sarajevo (u štampi).

${ }^{5}$ A. Šehović u svojoj monografskoj knjizi Jezik u bosanskohercegovačkim dramama (izd. Institut za jezik u Sarajevu) istraživala je i Isakovećeve drame (sa sociolingvističkog aspekta, izbjegavši mehanički opis formalnih obilježja jezičkih tekstova uspješnom primjenom diskursne analize i teorije govornih činova, odnosno istraživanja moderne pragmatike (Šehović, 2012: 13).

U Bošnjačkoj drami (Zagreb, 1996), koja je zamišljena kao antologija (uz dr. Maju Hribar-Ožegović, pisala sam recenziju), autor E. Sinanović piše o Isakoviću u poglavlju Suvremeno bošnjačko kazalište i drama. U knjizi se prvi put govori, koliko mi je poznato, i o scenskim elementima u bošnjačkoj svadbi, o bh. 'folklornom teatru' (po oskudnoj scenografiji sličnom elizabetanskoj i modernoj scenografiji, Isto, str. 40) i o tradiciji teatra sjena u Bosnu pristiglog s Turcima Osmanlijama. Za HribarOžegović bio je to dokaz o raskošnim mogućnostima bošnjačke drame i teatra unutar svjetske literature (Sinanović, 1996: 487). O dramskom postupku u proznom tekstu (i proznim remarkama) pisala sam u radu Glagoli govorenja u autorskim remarkama $i$ upravni govor (Književni jezik, XVI/3-4, Sarajevo, 1987), a o dramskom diskursu i upravnom govoru u Našem jeziku (izd. Publishing, Sarajevo, 2002) i u Lingvostilističkim zapisima (Zagreb, 2016). Svoj (teorijski) interes za dramu vezujem za inspirativno Čitanje pozorišta An Ibersfeld (Beograd, 1982). 
pisca Maka Dizdara (1917-1971) prilika za prisjećanje na tradiciju njegovanja glume na dvorovima bosanskih feudalaca. Svjedočanstvo o tome daje sam Dizdar u godini koju nije preživio. Naime, u svojim Starim bosanskim tekstovima Mak donosi pisani 'spomen' o tome kako bosanski feudalac Alibeg Pavlović šalje dvorsku družbu svojih glumaca (druga pol. XV st.) u Dubrovnik na proslavu Sv. Vlaha - kao što su ranije činili razni dostojanstvenici i kraljevi iz Bosne (Dizdar, 1971: 421). ${ }^{6}$ U pismu Oto poslah moje glumce poslanom dubrovačkom knezu i vlasteli Alibeg navodi:

Vlastele, ja ću $k$ vami pravo, a vi ka mnije kako vam je ugodno gospoctvu - da oto poslah moje glumce, Radoja Vukosalića s družbom, na vaše svetce. (Isto, 292)

I u svojim Marginalijama o jeziku i oko njega (1970), objavljenim godinu prije Starih bosanskih tekstova, pisac iz Stoca podsjeća na srednjevjekovne bosanske glumce i na staru bosansku riječ glumište:

U nas se od davnina glumilo (još u srednjem vijeku), pa su bosanski glumci išli u Dubrovnik da kao gosti glume na godišnjoj pokladnoj festi. Krajiški junak Osmanaga prezivao se Glumac, a takvih prezimena zadržalo se sve do danas. Mjesta gdje su glumci davali predstave nazivana su glumištima, pa zašto mi ne bismo sada u Sarajevu, Zenici, Mostaru, Banjaluci i Tuzli imali narodna glumišta, umjesto narodnih pozorišta ili kazališta, kada je glumište izvornije, narodnije i ljepše? (Dizdar, 1970: 119).

\section{DVADESETPETOGODIŠNJA PRAKSA I TRADICIJA}

U Marginalijama Mak se poziva na bosanskohercegovačku tradiciju, koja se u svakom slučaju mora poštovati $\mathrm{i}$ ističe da inzistiranju na vjekovnoj tradiciji ne može biti suprotstavljena misao o dvadesetogodišnjoj praksi kao novoj tradiciji ${ }^{7}$ (Isto, 119). Zato - u vezi

\footnotetext{
${ }^{6}$ Dizdarev je izvor: Ćiro Truhelka, Spomenici dubrovačke arhive, Sarajevo, 1911.

${ }^{7}$ Takva praksa nametala se pravopisnim i standardnojezičkim rješenjima sh./hs. jezika od Bečkog dogovora. O Rječniku sh./hs. jezika (Novi Sad, I-VI) svojevremeno je pisao D. Brozović u časopisu Kritika (1976) navodeći podatak da od djela koja u najširem smislu možemo smatrati literarnim, podjednak je broj (oko 225) i od hrvatskih, s jedne strane, $i$ od srpskih i crnogorskih, s druge. /.../ Muslimanskih (tj. bošnjačkih, isp. RHP) je pisaca relativno malo, oko 13 /.../. Za neliterarna djela ima
} 
s pitanjima leksike (uz terminologiju ${ }^{8}$ ili oficijelne nazive) i jezičke kanonizacije koja traži specifičan pristup i posebno rješenje zaključuje: praksom, naučno fundiranom, došli bismo do odličnih rješenja (Isto, 118).

I upravo jedanaeste godine od Makovih Marginalija, Alija Isaković započinje svoj rad na Rječniku karakteristične leksike u bosanskome jezika. ${ }^{9}$ Narednih deset godina radi na njemu i završava ga 1991. Među izvore $^{10}$ za svoj rječnik uvrštava i Makove Marginalije, ${ }^{11}$ gdje je Dizdar, vidovito kao 'nespina', zapisao i ovo: Leksičko blago za svoj vokabular jezički eksperti crpiće iz bogatih vlastitih izvora. (Isto, 118)

hrvatskih jedinica izvora oko 80, srpskih i crnogorskih oko 70, muslimanskih valjda 1 /.... Muslimani su ipak nešto zastupljeni (Brozovć, 1976: 38-44).

M. Dizdar je u to vrijeme predviđao: Leksičko blago za svoj vokabular jezički eksperti crpiće iz bogatih vlastitih izvora. /.../ Pravopis namijenjen stanovništvu Bosne $i$ Hercegovine /.../ će se služiti onim leksemama koje su žive u jeziku (Dizdar, 1970: 118). Nije se radilo samo o sitnicama, zaključio je Dizdar, pa o tome treba još ozbiljnije progovoriti (Isto, 114). O nevjerovatnim preinakama jezika bh. književnika (lektorskih, redaktorskih) u tematskom broju časopisa Život (1970) i u Rječnik A. Isakovića (str. 483-496). Vid. napomenu br. 21 u ovom radu.

${ }^{8}$ A rječnik općenito preko tog dijela dolazi u najbliži kontakt s onim što je vitalno $i$ zanimljivo u suvremenom životu i misli (Whitney, nav. prema: Bratinić, 1991: 109).

${ }_{9}$ Bosansko-turski rječnik (Magbuli arif) iz 1631., poznatiji pod imenom PoturŠahidija, učenog Tuzlaka Muhameda Hevai Uskufije prvi je $u$ Bosni $i$ Hercegovini $i$ kod Južnih Slavena samostalni dvojezični rukopisni rječnik napisan u stihu štokavskim dijalektom (piše A. Kasumović, u predgovoru ovog rječnika, v. Uskufija, 2012: 39). Uskufijin rječnik s nedvojbenim čuvanjem izvornih bosanskih riječi (A. Kadić, Isto, 48) Isaković je naveo kao jedan od izvora za svoj.

${ }^{10}$ Stare bosanske tekstove, u kojima je i Spomen o glumačkoj družini, Isaković nije uvrstio u izvore za Rječnik.

${ }^{11}$ Sarajevski časopis Život (1970, god. XIX, br. 11-12), čiji je glavni i odgovorni urednik bio Mak Dizdar, objavio je u istom broju, uz Marginalije, i Isakovićev tekst Varijante na popravnom ispitu - $\mathrm{s}$ još deset radova bh. lingvista, kulturnih i javnih radnika koji su se odazvali pozivu Uredništva Života da iznesu svoje mišljenje na temu: Tradicija, teorija i sadašnja praksa u primjeni književnog jezika u Bosni $i$ Hercegovini. 


\section{DVA ISAKOVIĆEVA DJELA}

Isakovićeve teorijske postavke o jeziku i vlastito iskustvo bh. književnika bliski su Dizdarevim. Dizdar je nedvosmisleno naglašavao da autohtoni, standardni jezik ovdje (u BiH, nap. RHP) nije podudaran s jezikom dviju vrijanata i da kanonizacija jezika u BiH traži specifičan pristup i posebno rješenje (Isto, 118).

U ovom radu fokus je na leksičkom sastavu Isakovićeve drame Hasanaginica (1982) ${ }^{12}$ s obzirom na postupke izdvajanja i tumačenje leksike $^{13}$ u njegovom Rječniku karakteristične leksike u bosanskome jeziku (1991). Cilj je utvrditi odnos riječi u drami Hasanaginica i leksema ${ }^{14}$ selekcioniranih u Rječniku - s polaznom pretpostavkom da postoji određena podudarnost u njihovom izboru, formi i značenju, pri čemu se ne gubi iz vida da su u pitanju dva različita tipa tekstova, vrsno i žanrovski, dva teže usporediva stila - književnoumjetnički (drama, tragedija) i primijenjeno naučni (rječnik, jednojezički), ${ }^{15}$ što za sobom povlači niz bitnih, međusobno suprotstavljenih distinkcija na planu leksike i njenog funkcioniranja u tekstu premda su i jedno i drugo, drama i rječnik, 'jeziku metajezici' (usp. Peti, 1995: 103), jedno in preasentia (drama), drugo in absentia (rječnik).

U analizi se dakle polazi od toga da dramu i rječnik čine komponente različite strukturno (s obzirom na mjesto u tekstu), formalno (s obzirom na način pisanja, iz čega proistječu brojne i bitne razlike, usp. Peti, 1995: 109), funkcionalno (s obzirom na uloge: 'drugostepeni modelativni sistem' i leksikografsko djelo) i jezičkostilski (s obzirom na vrijednosti i efekte). Koliko mi je poznato, za ovu temu do sada nije

${ }^{12}$ Godina nav. prema bibliografiji koju je sastavio M. Ćeman, v.: Alija Isaković, Taj čovjek, Pobuna materije, Svjetlost, Sarajevo, 1991: 366).

13 Pod leksemom se ovdje razumijeva svaka jedinica koja može doći u poziciju natuknice (riječ ili višečlani izraz, fraza).

${ }^{14}$ Čini se da je Isaković napravio ne samo stilski već i teorijski motiviranu razliku između termina riječ i leksema: jedno je jedinica realizacije ('jezika kao standarda'), a drugo (leksema) virtualna jedinica paradigmatske ose, tj. 'jezika kao sistema' (o čemu u kroatistici prvi piše prof. J. Silić, v. Kapetanović 2005).

${ }^{15} \mathrm{O}$ tome sam govorila na Naučnoj konferenciji Alija Isaković i bosanski jezik (14. marta 2017, Sarajevo) u radu Citati i fragmenti iz govora i jezika (Isakovićev Rječnik karakteristične leksike u bosanskome jeziku, balada Hasanaginica i istoimena Isakovićeva drama). Rad je objavljen u Zb. radova (izd. Institut za jezik, Sarajevo). 
bilo naučnih zanimanja niti je bilo istraživanja o njoj. ${ }^{16} \mathrm{U}$ radu sam se zadržala samo na određenim riječima iz drame preko kojih se mogu pratiti i u konačnici prepoznati bitne konture odnosa drame i Rječnika sa aspekta odabranog u ovom radu.

\section{IZVORI ZA RJEČNIK BEZ HASANAGINICE?}

U Rječniku je sabrano bh. leksičko blago kao karakteristična leksika u bosanskome jeziku uz važnu napomenu o koncepciji samog rječnika:

Na izvjestan način, ovaj Rječnik je rječnik književno sumnjivih riječi, značenjski $i$ normativno ambivalentnih, jezičkom isključivošću osakaćenih, nepriznavanjem osramoćenih; riječi (s više razloga) nepoznatih, protjeranih $u$ arhaizme, $u$ provincijalizme, $u$ tuđice, riječi $s$ indignacijom odbačenih, što ne priliči nikojem jeziku i ničijem pravopisu. Ovaj Rječnik je moje nastojanje da se tim riječima vrati njihova književna čast i javno uvažavanje. /.../ Nije svrha ovog Rječnika da vadi iz pepela neke arhaizme /.../. Ovdje su ispisani uzorci jezika kojim su pisali naši

${ }^{16}$ A. Šehović u svojoj monografskoj knjizi Jezik u bosanskohercegovačkim dramama (izd. Institut za jezik u Sarajevu) istraživala je i Isakovećeve drame (sa sociolingvističkog aspekta, izbjegavši mehanički opis formalnih obilježja jezičkih tekstova uspješnom primjenom diskursne analize i teorije govornih činova, odnosno istraživanja moderne pragmatike (Šehović, 2012: 13).

U Bošnjačkoj drami pak (Zagreb, 1996), koja je zamišljena kao antologija (uz dr. Maju Hribar-Ožegović, pisala sam recenziju), autor E. Sinanović piše o Isakoviću u poglavlju Suvremeno bošnjačko kazalište i drama. U knjizi se prvi put govori, koliko mi je poznato, i o scenskim elementima u bošnjačkoj svadbi, o bh. 'folklornom teatru' (koji je po oskudnoj scenografiji sličan elizabetanskoj i modernoj scenografiji, v. Sinanović, 1996: 40) i o tradiciji teatra sjena u Bosnu pristiglog s Turcima Osmanlijama. Za Hribar-Ožegović bio je to dokaz o raskošnim mogućnostima bošnjačke drame i teatra unutar svjetske literature (Isto, 487). O dramskom postupku u proznom tekstu (i proznim remarkama) pisala sam u radu Glagoli govorenja u autorskim remarkama i upravni govor (Književni jezik, XVI/3-4, Sarajevo, 1987), a o dramskom diskursu i upravnom govoru u udžbeniku Naš jezik 4 (izd. Publishing, Sarajevo, 2002) i u Lingvostilističkim zapisima (Zagreb, 2016). Svoj (teorijski) interes za dramu vezujem za inspirativno Čitanje pozorišta An Ibersfeld (Beograd, 1982). 
bosanski šukundjedovi, naši pradjedovi, naši djedovi $i$ očevi. (Rječnik, 493, 496) $)^{17}$

Zato je u rječničku građu Isaković unio brojna djela i to od sredine XVI pa do druge polovice XX st. Među izvorima navodi, između ostalih, i:

- bošnjačke narodne lirske pjesme (npr. zb. Od bešike do motike, $\mathrm{s}$ brojnim uspavankama i pjesmama za djecu, priredio Alija Nametak, 1970);

- bošnjačke narodne epske pjesme (npr. epska djela iz rukopisne ostavštine K. Hermanna, 1888; Pjesan naših muhamedovaca, zabilj. dr. F. Krauss u Dubrovniku 1886; Hrvatske narodne ženske pjesme /muslimanske/, obj. 1902. u Mostaru, sabrao i ur. Mehmed-Dželaluddin Kurt); spjev Ženidba Smailagić Mehe, kako ga je od A. Međedovića zabilježio M. Perry (Cembridge-Masachussett, 1935); Muslimanske junačke pjesme, 1943; zb. S. Nazečića Iz naše narodne epike, 1959);

- djela bh. alhamijado književnosti (npr. alhamijado pjesme Fejze Softe iz 18. st., a prema Hrestomatiji bosanske alhamijado književnosti pjesma Umihane Čuvidine iz 1813);

- listine, krajišnička pisma (odlomci iz krajišničkih pisama ${ }^{18}$ pisani arebecom ${ }^{19}$ uvršteni su u dramske didaskalije Hasanaginice) i druga pisma pogranične korespondencije od 16. st. (npr. pisma od 1583. do 1644. iz Bogišićeve zbirke omiških isprava XVI-XVII veka iz Spomenika Srp. kralj. akademije obj. 1940; Prepiska Vladike Rada s Ali-pašom obj. 1843; Rukoviet jugaslavenskih listina obj. u Starinama JAZU, Zg., 1878);

\footnotetext{
${ }^{17}$ Naslov djela u zagradi iza citata (ovdje: Rječnik) skraćenica je za Isakovićev Rječnik karakteristične leksike u bosanskome jeziku, a broj iza označava stranicu u Rječniku.

${ }^{18}$ Enes Kujundžić (1997) u Studijama o krajišničkoj epici navodi podatak da se $u$ Sandžaku upotrebljava naziv krajišnica (na Kosovu krešnica) općenito za hrišćansku pjesmu i da je arbanaški kreshnik ('junak') 'poarbanašeni' oblik reijči 'krajišnik', a da nema veze s krstašima, kao što misli E. Koliqi /nav. prema rukopisu rada Osobenosti bošnjačke tradicije u pluralističkom osmanskom društvu mr. Ramize Smajić, kojoj zahvaljujem na ustupljenom radu u rukopisu/.

${ }^{19}$ Isakovićev postupak se može usporediti sa Selimovićevim u Dervišu i smrti (istina, Ahmed Nurudin kaže da zapis svoj o sebi piše s desna na lijevo, tj. arapski).
} 
- riječi i fraze iz dosta izučenih hh. organskih idioma i rječničko blago brojnih rječnika (npr. govor Rame u istraživanju M. Okuke; rukopisne zbirke riječi bosanskoga jezika H. Rizvića i M. Abdagića; Bosnischturkische Sprachdenkmeler Otta Blaua, obj. u Leipzigu 1868; Rječnik turcizama A. Škaljića iz 1966);

- i usmene uspavanke, i Softino Ašiklijsko elif-ba, i epsku junačku pjesmu (npr. ona o ženidbi Kumalić Mujage) i riječi bh. dijalekata i govora odnosno organskih idioma svoga vremena (kao vlastito iskustvo stolačke, mostarske, sarajevske i tešanjske leksike).

U tome je sadržana svojevrsna matrica za razumijevanje Isakovićevog leksikografskog rada $^{20}$ i općenito odnosa prema jeziku i, konačno, odnosa - s ovog aspekta - njegovog Rječnika i drame Hasanaginica, koja je - što i sam naslov sugerira - još jedna suvremena dramska verzija, 'interpretacija", klasične muslimanske balade (Lovrenović, 1991: 12), s intekstno uvrštenim fragmentima djela iz rječničke građe (doslovnim fragmentima, citatima).

Svi ekscerpirani uzorci (oko 24 000), zapisao je Isaković, uneseni su u Rječnik, bez obzira da li su oni, u konačnome, bili prijeko potrebni (Isaković, 1992: 487). Kroz raznovrsne izvore reflektiraju se brojne karakteristične crte bosanskoga jezika uglavnom zanemarivane istiskivanjem brojnih riječi, izraza i oblika iz normi tada zajedničkog standardnog jezika (srpskohrvatskog/hrvatskosrpskog). Kao dijalekatske, regionalne ili lokalne uglavnom su smještane u pasivni leksički sloj. Odatle su ih pisci, kao iz depandansa, mogli uzimati kad

\footnotetext{
${ }^{20}$ Najveći doprinos književnika Alija Isaković bosnistici zasigurno i jeste, u području leksikografskog rada, njegov Rječnik s 13500 riječi (v. zagrebački časopis Behar iz 1993. i moj rad o Rječniku kao čuvaru identiteta i kontinuiteta bosanskoga jezika, koji je početkom 90 -ih reafirmirao svoje staro ime).

Isaković je rječničko blago strpljivo i akribično sabirao godinama iz raznovrsnih izvora nalazeći riječi i izvan bh. teritorije - $\mathrm{u}$ jeziku iseljenika u Turskoj. Zato u Izvorima konsultira brojne pravopise, gramatike i stare rječnike s kojima je, kako kaže, ,vršeno poređenje“ (Rječnik, 37), npr. rječnik Fausta Vrančića, Belostenca, Dela Belle, Mikalje... A izvori su mu i Gundulićev Osman i rječnik uz Njegoševa djela i, kako sam navodi, ,brojni autori kao zanimljiva potvrđivanja ili negiranja nekih riječi i oblika" (Isto, 36).
} 
su im bile potrebne, obično za govornu karakterizaciju likova (a mogle su se naći i naučnom tekstu, u dijalektološkim radovima).

Isaković prepoznaje brojne takve zaboravljene riječi i njihove oblike $\mathrm{i}$ popisuje ih u svom Rječniku karakteristične leksike u bosanskome jeziku (41-479) pažnju usmjeravajući upravo na izraze i značenja riječi protjeranih u pasivni fond, u prostor dijalekatskog i provincijalnog, općenito neknjiževnog ili nestandardnog. S pozicije koncepta identiteta jezika bi bilo neobično da svoju Hasanaginicu Isaković ne uvrsti u građu za Rječnik. No, tako je kako nam se čini! Naime, uz natuknicu zijehati Isakovićev Rječnik ipak upućuje na dramu Hasanaginica kao jedan od izvora. Isaković, naime, ovu riječ ovjerava svojom Hasanaginicom. ${ }^{21}$

Alija Isaković je u Izvore uvrstio, kao što smo vidjeli, klasičnu muslimansku baladu (Lovrenović, 1991: 12) po čijim je motivima i predlošku napisao istoimenu dramu, i to prvi zapis te balade (A. Fortisa iz 1774), tj. posredstvom nautuknice zijehati doveo nas do podatka da je u građu ipak uvrstio i svoju Hasanaginicu, objavljenu one godina kada je, po vlastitom svjedočenju, već bio počeo svoj desetogodišnji rad na Rječniku. ${ }^{22} \mathrm{Uz}$ navedenu natuknicu, naime, Isaković donosi citat iz te drame (rječnički su navodi u isto vrijeme posredna potvrda da značenja leksema i njihova 'upotrebna vrijednost' ovise o rečeničnom kontekstu):

Da babine desnice i babinog buzdohana ne bi, još bi njihove glave zijehale s duvarova po Kotarima. (Isto, 226)

Navedene riječi pripadaju Hasanaginoj majci, a u Rječnik su uvrštene zbog glasa $h$ i njegove 'odbrane'. U ranijim pravopisima, kao što je poznato, prednost se u pravilu davala riječima bez $h$ (što je pravdano 'slabom artikulacijom' glasa $h$ ) i riječima sa $v$ ili $j$ na njegovom mjestu (npr. suvo, snaja), o čemu je pisao i sam Isaković u Post factumu, na

\footnotetext{
${ }^{21}$ A to što u Rječniku nije navedena autorova drama Hasanaginica u dijelu Izvori, koji raspolaže s preko 150 drugih djela, može biti slučajan propust. Zasigurno bi ostalo neobično da je drama ostala izvan građe Rječnika. No, Hasanaginica je u Rječniku, makar to bilo samo zbog ove natuknice, kao što je i Rječnik u Hasanaginici.

${ }^{22}$ Od vlastitih, u izvore je Isaković uvrstio samo jedno djelo - Taj čovjek (Mostar, 1975).
} 
zadnjim stranicama svoga Rječnika. ${ }^{23} \mathrm{~A}$ ispustiti glas h iz svoga slova, bio je jasan Stočanin Dizdar, bilo bi isto kao što bi neki kompozitor izbacio upotrebu jedne note iz muzičke skale, ili jedan kemičar bilo koji element iz Mendeljeevog sistema, ili jedan graditelj jednu stepenicu u stubištu jedne zgrade. (Dizdar, 1970: 119)

\section{DIDASKALIJE i bakva, 'igra slična golfu'}

Cjelovit mikrosvijet drame grade dva dijela jezičkostilski i funkcionalno različita iako, u načelu, iza cijelog teksta dakako stoji (jedan) autor. U drami su, naime, obično oponirani 'autorski' dio teksta ili didaskalije (nekada slikovitije nazivane scenske napomene i režija), $\mathrm{s}$ jedne strane, i govor likova ili dramske replike, s druge, kao što u rječnicima naspram autorskog teksta (uključuje izbor/neizbor natuknice, tj. leksičke jedinice, i njenu jezičku 'obradu') stoje citatni dijelovi, neautorski ili 'tuđi' dio teksta odnosno 'tekst u tekst' (ponavljanje već 'viđenog', pročitanog, odnosno - poznatog).

Didaskalije, koje određuju modalitet glume na pozornici, u pravilu pisane drugim tipom pisma, ${ }^{24}$ obuhvaćaju opise određenih situacija $\mathrm{i}$

${ }^{23}$ U Rječniku Isaković piše: „Nisu bile u pitanju samo pravopisne norme. Književnojezička stvarnost bila je ponekad grublja. Postoje brojni oblici koje je Pravopis (iz 1960., nap. RHP) dozvoljavao (...bahahat, bahuljati, čahura, halav, sumahnut, harčiti), ali ovih oblika nije bilo u javnoj upotrebi, čak ni u Bosni i Hercegovini gdje su te riječi materinske, većini stanovništva; nije ih bilo pošto su majorizacijom i brojnim nepovoljnim analogijama naprosto postale nepoželjne. Sličnu sudbinu doživjela je i leksika bosanskoga jezika i ranijih desetljeća, zapravo, cijelo stoljeće“ (Rječnik, 484). Danas ovi podaci zvuče nevjerovatno: „Fridrich Krauss u bilješci, na kraju epa Smailagić Meho (1886), kazuje da mu je izdavač riječ kahva zamijenio riječju kava, a mehko u meko. Iz bilježaka uz priređena djela E. Mulabdića (Pripovijetke, knj. II, Sarajevo 1074) i Osman-Aziza (Pripovijetke, Sarajevo 1980) vidljivo je da su urednici Matice Hrvatske, s kraja prošlog vijeka, vršili nasilje nad autorskim jezikom. 'Našim piscima osamdesetih godina prošloga stoljeća jezike (je) ispravljao urednik izdanja Matice Hrvatske', piše Josip Hamm u Uvodu Benešićevog Rječnika hrvatskoga književnoga jezika (Zagreb, 1985, XVIII). U Mulabdića je ko mijenjano u tko, Allah u Alah, lahko u lako, daidža u ujak, zrak u vazduh i sl.). /.../ Narodna uzrečica 'Pomalo, Muho, pošlje ćeš suho!', objavljena je u jednom sarajevskom listu 'Pomalo, muvo, pošlje ćeš suvo!' (M. B., Odjek, VI/1955, 9 (59) 7)“. (Rječnik, 484-5)

${ }^{24}$ I obično stoje u zagradi. Nominacija lika, kojem u drami pripadaju riječi iza imena, tj. identifikacija govornika, važna je komunikacijska funkcija didaskalije. 
stanja, govora likova i navode prateće neverbalne znake (mimika, geste, način kretnji), zapravo pojašnjavaju pojedine postupke likova, izraze lica i pokrete (signali moći vizualnog i auditivnog na sceni, 'tijela' povezanog s glasom, koji je u konačnici i sam 'tjelesnog' porijekla). I to im je osnovna funkcija. ${ }^{25}$ Obično su kratke, ponegdje minimalne (Sofoklo, Shakespeare), a mogu biti i bogate (Krleža, Marinković).

Autori u njima sa svoje tačke gledišta daju obavijesti ili objašnjenja čitatelju odnosno upućuju redatelja i glumce kao neko ko je 'spolja' (zato se u predstavi i ne 'govore'), a s obzirom na takvu poziciju očekuje se da njihov jezik pripada standardu. I tako jeste: autorski je govor, $\mathrm{u}$ pravilu, na standardnom jeziku. Zato i Isaković piše rzanje u jednoj dramskoj didaskaliji svoje Hasanaginice, prema tadašnjoj standardnojezičkoj normi: Čuje se konjski topot i rzanje Hasanaginica, 237), a u Rječniku, u dijelu Kako dalje?, desetak godina iza toga, objašnjava:

Naša književna $i$ naučna baština pravopisno je nagrđena $u$ posljednjih stotinjak godina te će se jednom javiti potreba da se djela prirede prema pravopisu bosanskoga jezika, da bi se vratio prirodan autorski tekst, prirodni pravopisni, leksički i morfološki oblici koji su bili uskraćeni onovremenim, tuđim, jezičkim normama.

/.../ Bosanski muslimanski pisci izgovaraju i pišu h, bez obzira da li je ono tu bilo ili se razvilo iz drugog glasa: u domaćim riječima /.../ i turcizmima (mahana, mahrama, hrđa, hrvati se, hrzati...). (Rječnik, 488-9)

U Isakovićevim didaskalijama u Hasanaginici pojavit će se i riječi poput bakva i pala. Kad daje opis dječije igre pred Hasan-aginom odajom, autor obje riječi stavlja pod navodnike i nakon toga ih protumači, jednu (a) postupkom sličnom definiranju u postpoziciji, a drugu (b) sinonimnom leksemom stavljenom u zagradu:

(a) Djeca se igraju "bakve", stare igre koja je slična hokeju na travi.

${ }^{25}$ Posebno je važna njihova uloga u razvoju dramske radnje i dramskog sukoba. 
(b) Kad neko od njih postigne pogodak "palom" (štapom), svi to poprate grajom i veselim klicanjem. (Hasanaginica, 277) ${ }^{26}$

Svjestan prostorne ograničenosti riječi bakva (Stolac) $^{27}$ i vremenske udaljenosti kao stare igre (može pripadati frazeološkoj poziciji djece toga prostora i vremena), autor pod navodnike stavlja $b a k v u$, ali i s njom povezanu palu. Formalno ih obje 'očuđuje' pravopisnim znacima (navodnici) i u samoj didaskaliji pojašnjava na dva načina. Za potpunije prenošenje 'kulturno-civilizacijskog sadržaja' lekseme bakva (značenje lekseme, znanje denotata) autor daje minimalni opis s poređenjem (up. slična hokeju na travi), a uz palu navodi sinonimnu leksemu štap, s kojom pala dijeli isti plan sadržaja.

Obje su lekseme zabilježene u Rječniku karakteristične leksike. Prva, bakva, po stolačkom izvoru je 'ploča - meta u koju se udara u seoskoj igri sličnoj golfu', a druga, pala, znači 'lopata' (kao izvor za ovo značenje Isaković navodi Nametka i njegov Jezik naših iseljenika $u$ Turskoj). Ona u Rječniku ima i svoj homonimski parnjak (leksički homonim) sa značenjem 'dvosjekli mač' (kao izvor autoru je poslužio Škaljićev Rječnik turcizama) $)^{28}$. U konkretnom tekstu, u didaskaliji svoje Hasanaginice, Isaković bakvu tumači na sličan način, kako je već rečeno, dakle postupkom rječnika: iza lekseme bakva, u postpoziciji navodi da je to 'stara igra slična hokeju na travi' (u odgovarajućem gramatičkom oblikom, dakako, jer je u didaskaliji dio iskaza). Leksemu pala tumači sinonimom, što je također rječnički postupak, ali i 'distancirano' (sinonim je u zagradi).

Značenja u Rječniku karakteristične leksike i u drami Hasanaginica, doslovno prenesena iz starije Hasanaginice u kasniji Rječnik, jesu slična, no nisu identična (up. 'štap' / 'dvosjekli mač', 'hokej na travi' /

\footnotetext{
${ }^{26}$ Naslov u zagradi odnosi se na Isakovićevu dramu Hasanaginica, u: Drame (Isaković, 1995).

${ }^{27}$ U Rječniku uz natuknica stoji da je stolačkog porijekla.

${ }^{28}$ Up.: pala (2) Škaljić, 'dvosjekli mač' (Rječnik, 304). Kod Škarića je pala turcizam i ima dva značenja, jedno, koje navodi Isaković u Rječniku, 'dvosjekli mač', i drugo koje navodi u Hasanaginici - 'štap kojim se igra klisa (pala i klis)'. Značenje 'lopata' od lat. je riječi pala (1), a značenja 'sablja' i 'štap' od turcizma pala (2), up. S. Halilović, I. Palić , A. Šehić, Rječnik bosanskog jezika (2010). Zapravo pala (1) i pala (2) homonimski su par, i to homografi: lat. ima dugi uzlazni akcent, a tur. kratki uzlazni.
} 
'igra slična golfu'). Riječ pala pak lakše se može dovesti u vezu s riječi palica 'drvo u obliku štapa s vrlo raznolikom namjenom'29 nego povezati s 'dvosjeklim mačem' ${ }^{\prime 30}$ (kako Isaković navodi u svom Rječniku pozivajući se na Škaljićev) ili s 'lopatom' (značenje sačuvano u starom bosanskom jeziku naših ljudi iseljenih davno u Tursku, kako Isaković navodi pozivajući se na A. Nametka). Lovrenovićevo se zapažanje da u svojoj Hasanaginici Isaković prakticira postupak svojevrsne rekonstrukcije historijskoga okvira $i$ kulturološkoga materijala (Lovrenović, 1991:12) možda na ovom planu najlakše potvrđuje, tim prije što to za njega kao pisca nije karakteristično (Isto, 1991).

Sličan postupak didaskalijskog pojašnjenja značenja riječi, s različitom podlogom oneobičavanja i stilematičnosti, Isaković primjenjuje i na drugim mjestima u didaskalijama svoje Hasanaginice (c), npr. uz riječ pasivnog fonda jenđija:

(c) Hasanaginica u feredži i jendžija (obikuša) uz nju. Tek su se sada pojavile... (Hasanaginica, 276)

Polazeći od uvjerenja da čitatelj možda neće razumjeti leksemu jenđija, kao što je pretpostavio da neće razumjeti bakvu i palu, Isaković 'ponavlja' plan sadržaja riječi neposredno uz jenđiju i u zagradu (na mjesto sinonima) stavlja riječ obikuša. Taj 'dopunski' (u zagradi) sinonim, čini se, čitalac ipak i ne može dovesti u vezu s leksemom jenđija tako jednostavno kao što bi mogao npr. palu s palicom. Uz to prva riječ u ovom sinonimnom paru (jenđija) nije 'očuđena' stavljanjem pod navodnike (kao što su bakva i pala, npr.) jer ovaj turcizam nije lokalno (teritorijalno) ograničena leksema, kao što nije ni turcizam harfovi iz jedne druge didaskalije, gdje prepoznajemo postupak prepozicijski pojašnjenog značenja turcizma u apozicijskoj poziciji

\footnotetext{
${ }^{29}$ Up. Rječnik bosanskoga jezika u izd. Filozofskog fakultete u Sarajevu, 2010.

${ }^{30}$ Uz riječ klis, koja se nalazi u RMSMH i u Rječniku moje majke, Prilog rječniku blaga bosanskoga jezika Seada Trhulja (2011), stoji: „U tradicionalnoj dječijoj igri klisa i mačke, riječ klis označava 'komad oblog štapa, zašiljen s obje strane, a mačka 'palicu u igri klisa' (u Isakovićevom Rječniku ih nema).“ U istočnoj Bosni slična igra poznata je pod nazivom 'igra pale i klisa' (klis je daščica u obliku baklave, koja je meta kao bakva, a pala je skraćenica od 'palija' = štap kojim se pogađa klis).
} 
(harfovi) s naknadnim, distaktnim preciziranjem (arapski alfabet), primjer (d):

(d) Hasanaginica pokriva bešiku, ustaje pokušava da bude dobra s djecom uzima gajtan da pomoću njega oformljuje slova, harfove, $i$ pokazuje djeci, učeći ih arapski alfabet. (Hasanaginica, 229)

U Rječniku su jenđija i obikuša također natuknice; jenđija je objašnjena kao 'svatica, djeveruša', dok za polisemičnu obikušu Isaković navodi ova značenja: 'žena ili djevojka koja uz mladu boravi u mladoženjinoj kući dok se mlada ne obikne' i 'kahva'. Polisemija ne postoji u govoru (realizaciji), pa će u tekstu drame ova riječ ostvarivati samo jedno od značenja, i to prvo - što ga je sam kontekst 'zadao' ili 'odabrao'. Naime, značenje sinonimne riječi obikuša - osoba u Hasanaginicinoj pratnji radi njena 'obikavanja' u novoj sredini u koju odlazi udajući se - čitalac može razabrati iz konteksta. Do značenja navedenog u Rječniku ('žena i djevojka koja uz mladu boravi u mladoženjinoj kući dok se mlada ne obikne') čitatelj može doći preko glagola obiknuti se 'naviknuti se', koji se, s navedenim značenjem, također nalazi u Rječniku.

No, u Rječniku nema jedne druge rjeđe upotrebljavane riječi: nun. I nju nalazimo u dramskoj didaskaliji. U Rječniku leksema se nun i ne očekuje s obzirom na koncepciju djela. Zbog toga se uostalom ni frekventniji i u bosanskom jeziku običniji turcizam harf općijeg značenja ('slovo') neće naći u Rječniku. Kao neka vrsta 'kulturno označene riječi' (Bratanić, 1991: 151) nun u drami funkcionira u kontekstu karakteriziranja likova u jakoj opoziciji: Hasanaginice i njene svekrve ili, općenitije, dviju sukobljenih porodica, aginske i begovske, Arapovića i Pintorovića.

Naime, autoru je bilo dovoljno da riječ nun, kad se prvi put pojavila u drami, u samoj didaskaliji protumači kao konkretno slovo ' $n$ ' jer je u jednoj ranijoj didaskaliji već naveo da Hasanaginica s djecom uzima gajtan da pomoću njega oformljuje slova, harfove... učeći ih arapski alfabet. Riječ nun pojavljuje se dakle nakon što je u prethodnoj didaskaliji već bila dovedena u vezu s igrom slova (harfova) arapske abecede. Kao hiponimu (u odnosu na harfove kao 'slova', 'arapski alfabet') slovu " $n$ " je u neposrednoj postpoziciji samo otkriveno, tj. precizirano ime: nun. Na taj su se način riječ i ono što ona znači, tj. nun 
i slovo ' $n$ ', našli u obrnutoj poziciji, inverzibilnoj u odnosu na onu koja označava lijevu i desnu stranu u rječniku (e):

(e) Starija kćerka pokazuje slovo "n", nun, i govori... (Hasanaginica, 229).

Da se nalazi u rječniku, natuknica nun našla bi se u prepoziciji (lijeva strana), na strani na kojoj stoje sve lekseme kojima se tumači značenje (koje je desnoj strani). Pozicija 'iza' signalizira da je Isakoviću više stalo, slično kao u postupku (d) s riječi harfovi i naknadno 'izlučenim' značenjem arapski alfabet, do posredne karakterizacije junakinje (porijeklom iz begovske porodice, Hasanaginica je već naučila djecu 'pismenima' jednog svjetskog pisma) nego do same postpozicijske identifikacije konkretnog slova imenom, tj. reimenovanja preciznim arapskim nazivom slova koje agina starija kćer 'piše' gajtanom. Isto je i sa slovom vav:

Hasanaginica je oformila slovo " $v$ ", vav. (Hasanaginica, 230)

\section{GOVOR LIKOVA - prva polovica 17. st.}

U didaskalijama se sreću i ovakve sumnjive riječi, kako bi kazao Isaković, riječi nepriznavanjem osramoćene i jezičkom isključivošću osakaćene, lekseme koje 'traže' vraćanje časti i javnog uvažavanja (Isaković, 1992: 484): beg, odaja, leđen, đerđef, bajrak, kafez... ${ }^{31} \mathrm{~S}$ obzirom na temu i vrijeme koje je dramom zahvaćeno, posve je očekivano da se jave u dijalogu i monolozima likova, no u njihovom govoru ne mogu biti, kao takve, ni arhaizmi, ni historizmi. U didaskalijama glas autora dolazi iz kasnijeg vremena, vremena čitatelja, i on govori jezikom doba iz kojega su ovakve i slične riječi (ili/i njihovi oblici), i kad su karakteristične u bosanskome jeziku, protjerane $\mathrm{i}$ zaboravljene; on govori jezikom svoga doba, ali koristi se ovim riječima kao činjenicom koja nije nestala iz drugostepenog modelativnog sistema i iz jezika, unatoč lektorima ili urednicima izdavačkih kuća. ${ }^{32}$ $\mathrm{U}$ Rječniku ih pak nalazimo, očekivano - s obzirom na njegovu

\footnotetext{
${ }^{31}$ Drami je, kao što je poznato, prethodilo Isakovićevo seriozno, temeljito istraživanje koje je rezultiralo zbornikom Hasanaginica 1774-1974. Prepjevi, varijante, studije, bibliografija (Svjetlost, Sarajevo, 1975).

${ }^{32} \mathrm{~V}$. citat iz Rječnika u fusnoti 24.
} 
koncepciju. Isaković je u dijelu Post factum (podnaslov Kako dalje?) napisao:

Što se bosanskog jezika tiče, turcizmi su ušli u nj kao senzacionalna nomenklatura nove civilizacije i kao nova islamska duhovna sadržina, privatni i javni život. (Rječnik, 488)

No, mnoštvo turcizama, napomenuo je, u Rječniku je naprosto zbog normativnih, pravopisnih razloga jer $i$ u Škaljića i drugdje ima odveć načina na koje se pišu iste riječi te sam želio dati prednost nekim oblicima. (Isto, 488-9). Dodali bismo: njih je tražilo vrijeme prve polovice 17. stoljeća i prostor o kojima drama govori, a Rječnik karakteristične leksike u bosanskome jeziku pronašao ili ovjerio. Posve je jasno i to da dramski dijalog, kao književnoumjetnički, nije isto što i tzv. svakodnevni: dijalog u drami uvijek je estetski čin.

Neke od riječi, zaboravljene, Isaković unosi u Rječnik, npr. đerđef 'drveni ram na koji se zateže platno za vezenje'; leđen ' lavor za umivanje, legen'; odaja 'soba na katu, soba'. No, to što uz natuknicu nije navodio njihovo etimologijsko porijeklo, valjalo bi razumjeti kao Isakovićevo zanimanje za činjenicu bosanskoga jezika ili ono što je u jezik još davno upisano, a dijelom iskrivljivano ili istiskivano iz standarda, pa je i sam đerđef, rekla bih, u Rječniku zbog alternacije $f: v$ (zbog koje se pojavljuje lik đerđev, usp. Škaljić 1989), leđen zbog oblika legen (prema pers. legen, usp. Škaljić 1989), odaja ${ }^{33}$ vjerovatno zbog toga što je uzimana kao "usvojena tuđica sa značenjem soba, ali taj status nije imala u tadašnjem jeziku" (v. Sinonimi i srodne reči u srpskohrvatskom jeziku 1974: 740).

Iz istih razloga, može se pretpostaviti, u Rječniku nema dolame ni feredže naprimjer, koje se pojavljuju u drami, no ima riječi pravopisno ocjenjivanih kao nestandardne iz nekog razloga ili im po procjeni tadašnjih normativaca nije davana ravnopravnost ili prednost (up: bajrak-barjak, kafez-kavez, lagahan-lagan).

Zato ni uz natuknicu beg, titulu koja u drami funkcionira kao oznaka društvenog statusa porodice Pintorović naglašeno više rangirane i u opoziciji prema tituli glavnog junaka Hasan-age, u drami koja se događa u prvoj polovici 17. stoljeća (v. Hasanaginica, 1995: 218),

${ }^{33}$ Otuda: odabaša 'portir u hanu', odadžija 'sobar, sobarica', v. Škaljić 1989. 
Isaković ne navodi značenje, već samo 'citatni' primjer: Kasim-beg. Bitan mu je način pisanja titula beg i aga: kad su iza ličnoga imena, polusloženice su (Hasan-aga, sandžak-beg Pintorović, Alija-beže). I u usmenoj baladi, koju je Isaković unio u dramu i uvrstio u svoj Rječnik, titula aga piše se na isti način kao u drami (Hasan-aga), ali ne i titula beg (up. već daidža, Pintorović beže $e^{34}$, s vokativom titule uvjetovanim metrom), što je indirektni signal opravdanosti potrebe Isakovićevog ujednačavanja pravopisnog pravila.

U Hasanaginici pak Isaković bega Pintorovića ponekad imenuje samo titulom (beže). Begom ga oslovljava ${ }^{35}$ Abid, nešto stariji od Bega, s ratničkim ožiljkom na licu (Hasanaginica, 234). Abid je niže rangiran od bega Pintorovića (beg se Abidu obraća ličnim imenom - moj Abide, upućuje mu imperative), no Hasan-agin sluga, istina u neizravnom oslovljavanju, uz titulu svoga gospodara navodi i agino lično ime (Hasan-aga te selami i poruča ti da ga ne čekaš; Hasanaginica, 236). Razlog tome mogu biti čitatelji, još više gledatelji predstave, koji na početku scene u kojoj se javljaju ove riječi, kad Hasko ulazi u odaje gdje se Hasanaginica igra sa svojom djecom, ne moraju odmah znati od koga aginici dolaze vijesti ni kako je Abid pozicioniran (Hasko će i kasnije reći Hasan-aga, ali i upotrijebiti atributiv sam - aga, no ni tu i nije riječ o njegovom izravnom obraćanju agi).

Razlozi zbog kojih Isaković u svoj Rječnik unosi titule beg ili aga, pravopisni su, rekla bih. Zato uz natuknicu beg stoji samo primjer (Kasim-beg) i izvor iz kojega je preuzet. Uz drugu natuknicu, prije nego što unese njeno značenja ('gazda, gospodar'; 'prvak, vojni zapovjednik'), Isaković navodi tri potvrde istog (polusloženičkog) načina njenog pisanja kad je iza imena (Ahmed-aga, Memiš-aga, Numan-aga) i dodaje izvore (prvi: Pisma, 1634). To bi trebalo biti ovjera tradicionalnog načina pisanja titula beg i aga kad stoje uz lično ime.

Nositelji titula, Pintorovići i Arapovići, u drami su pak sami aktualizirali značenje svojih dviju titula različito pozicioniranih i vrednovanih u vremenu i prostoru u koji su smješteni. ${ }^{36}$ Ono što je u

\footnotetext{
34 Na str. 214 u baladi koju je Isaković unio i u 'predtekst' drame.

${ }^{35}$ Srodničkim terminima oslovljavaju ga majka (sine) i sestra Hasanaginica (brate).

${ }^{36}$ V. rad Žic-Fuks, 1989, Osnovna obilježja oslovljavanja u Zagrebu, SOL, 7/1, $27-$ 38.
} 
značenju oponiranih titula distinktivno i bitno jeste status njihovih nositelja u sredini i u usmenoj tradiciji, a to su sami izrekli (čitatelju, gledatelju) kroz brojne replike otvorenog dramskog sukoba u odajama, kliškim i zagvozdskim. Tako majka bega Pintorovića, kao i sam beg, agu spominje kao Hasan-aga (Morebit Hasan-aga i nije toliko kriv, 242; Hasan-aga vida rane na Biokovu, 243), a agina majka Hasanaginicinog brata imenuje samo titulom beg $(239,246)$, kao i njen sin Hasan-aga (Sve je beg sevep, 246; a beg učinio što sam mu ja nanijetio, 246). U didaskaliji pak autor, u pravilu, Hasanaginicinog brata imenuje s titulom u prepoziciji (beg Pintorović), no napisat će i ovako: Pored Bega su Abid... (Hasanaginica, 248). Titula beg dobila je 'antonomazijsku' ulogu budući da se može razumjeti kao 'eliptirana' sintagma (Beg) s funkcijom cijele sintagme (beg Pintorović).

Kad je riječ o turcizmima, Isaković ih u Rječniku ne favorizira, kako je i sam naveo; uzima ih kao bitnu odliku jezika i metodom ilustrativne citatnosti potvrđuje (ovjerava) njihovo postojanje u tradiciji. Zapravo govori i o pravopisnim pitanjima i načelima izgovora i njihovog bilježenja dajući prednost nekim oblicima, npr. daidža, kako je riječ zabilježena i u njegovoj Hasanaginici a i u istoimenoj baladi.

Riječi snaha i snahica (Hasanaginica, 227-8) iz istog su semantičkog polja, no u Rječniku su i one uglavnom zbog glasa $h$. Kad je u pitanju glas $h$, on se, kao što je poznato, izgovara i piše gdje mu etimološki jeste, a i gdje nije mjesto, up. riječi s naglašenim 'identitetom': uho, rahat, helač, hala, sahat, lahko, polahko, mehkim (lahako i mehko su zabilježene u tekstovima iz XVII st., lahak i mehak iz 1886. g. - kako Isaković navodi u Rječniku), mehlem, muhur, hojrat, hodža, hizmet, haber, halalolosum, uhvate, tahte, sveho. Sve ih nalazimo u replikama u Hasanaginici, ali i u Rječniku. Nalazimo i riječi nahudimo, nahudila. Kao natuknicu, Isaković riječ nahuditi dovodi u vezu sa značenjem 'nauditi' i upućuje na gl. huditi. Ovjeru nalazi u: Kapetanović 1887. i napominje: Današnja jezička svijest stavlja ga (uditi) $u$ vezu sa hud $i$ pisci pišu huditi (na-), naškoditi. A riječ hud objašnjava kao 'slab, jadan, bijedan'.

Zato u Isakovićevoj drami (u njenim replikama) možemo naći, s metajezičkog aspekta, i ono što o tradiciji fonološkog pravopisa od srednjovjekovnih zapisa imamo u bosanskome jeziku: imoski kadija, $u$ 
Imoski, do Imoskog. U Rječniku pak nalazimo potvrdu za njih (npr. Imoski Kadia - 1774; imočki kadia - 1621, imocki - 1634).

I ikavica je za bosanski jezik karakteristična do kraja 19. stoljeća, pa u drami nalazimo i brojne riječi s ikavskim refleksom staroga jata (gdi $268^{37}$, ovdi 235 , vidit će 235 , priko 233 , divojka 250 , pisma 249 , pivan 249 , prikoreni 250, srio 258) uz ijekavizme (djetinjsvo 266, nedjelja 266, ljepša 265, djeca 268, tjera 270, nevjesta 232, lijepa 268, izmijenio 270, otjerao 272, voljela 262). Ti se oblici isprepliću u govoru istoga lika (up. radije bi podnijela Hasan-agin tabijat... tu - gdi mi djeca rastu, 268; Neno, gdi je moja majka, 264). U nekim bi se primjerima oblici mogli tumačiti dakako i kao utjecaj balade.

Drama svjedoči i o udvojenim suglasnicima (npr. džennet 255, Muhammed 275, Allah 273). U drami su i riječi s karakterističnim pridjevskim nastavcima - iji (Božijim 239), elizija u infinitivnom nastavku gl. na - $t i$, i danas raširena osobina razgovornog jezika (pušćat 272, moglo se natjerat 263, nemoj me davat 265, ne može podnijet 267, njemu je lahko pušćat $i$ svezat 257, nemoj mene davat 265, ne smiješ pogazit 267, neću bit kadra 270, život ću založit 267). O leksičkom bogaćenju semantičkim diferenciranjem pojedinih riječi-parova svjedoči primjer ženska oćutjeti 276 sa značenjem 'osjetiti' (u Rječniku Isaković bilježi dva značenja: uz 'osjetiti' navodi i 'čuti, očuti, slušati').

\section{DIDASAKALIJE I DIJALOG - postupak vela i duvaka}

Drama Hasanaginica nastala u jednom historijskom trenutku, govori o jednom historijskom vremenu. Vezuje se za 17. st. U njoj se sve događa u prvoj polovici 17. st., kaže Isaković u predtekstovnom dijelu. $\mathrm{Na}$ raspolaganju mu stoji fond leksike iz depandansa, rezerve iz koje se crpi potrebna leksika kad je potrebna. S aspekta savremenog čitatelja - to znači: mnogi historizmi, turcizmi, dijalektizmi, lokalizmi.

Kako funkcioniraju neke od ključnih riječi u Isakovićevom dramskom tekstu mogu ilustrirati i sinonimne riječi veo i duvak u zadnjoj sceni Hasanaginice, presudnoj za dramsku egzistenciju Hasanaginice (kao i u baladi). Riječi imaju jasnu distribuciju: jedna pripada autoru, druga

${ }^{37}$ Broj označava str. Hasanaginice (izd. 1995). 
liku. Veo (na Hasanaginici, u svatovima) srećemo u opisu scene pred aginom odajom:

Hasanaginica gleda preda se. Veo nas sprečava da vidimo kako joj je. (Hasanaginica, 277).

Riječ duvak ne nalazimo u autorskom jeziku, pojavljuje se samo $\mathrm{u}$ replikama dvojice svata, koji su u funkciji 'komentatora' i dopunjavaju ono što čitalac ne vidi, a likovi ne znaju. Njihov je govor

'živa riječ' junaka iz 17. st., kako bi rekao Isaković.

U Rječniku se riječ duvak tumači kao 'mladinski veo'. Kao izvor za ovaj turcizam Isaković navodi 'nar. pjesma' - i to je sve o duvaku u natuknici.

U drami Hasanginicino lice skriva veo, navodi se u didaskaliji. Veo je ono što je u usmenoj baladi duvak do koljena. Duvak će se pojavit najprije u komentaru II Svata:

Umalo mlada ne izgubi duvak, prije vakta i takata! (Hasanaginica, 276)

Duvak joj je podugačak. Poručila je taki duvak od mladoženje da ne vidi kako će do njega doći. (Hasanaginica, 277)

Hasanaginica je i u feredži, napominje se u didaskaliji, a dva svata $\mathrm{u}$ dijalogu nagađaju: duvak nosi da ne vidi svoju djecu ili da djeca nju ne vide i poznadu ili da ne vidi kako će do mladoženje doći. Nakon toga dolazi u autorskoj didaskaliji sinonimna imenica veo:

Hasanaginica gleda preda se. Veo nas sprečava da vidimo kako joj je. (Hasanaginica, 277).

pa u replici II Svata ponovo duvak:

Ako snimi ${ }^{38}$ duvak, konac ti je našemu svatovanju... (Hasanaginica, 279)

Naime, stojeći podalje (278), okrenut djeci i svatovima, u ovoj sceni Hasan-aga ne vidi lice mlade u svatovima, no zna da je to Hasanaginica, 'ona'. Granica je uspostavljena ženskim odjevnim predmetom u

${ }^{38}$ Skine (riječ se, s tim značenjem, nalazi u Rječniku). 
svatovima. Veo skriva njeno lice, njen identitet. ${ }^{39} \mathrm{~S}$ njim i emociju. $\mathrm{Na}$ granici dvaju prostora, svoje odaje i vanjskog svijeta, na samom rubu vlastitoga prostora (s vrata svojih odaje) naći će se Hasan-aga. Hasanaginica je zaštićena velom. Veo nas sprečava da vidimo kako joj je. - bilježi dakle autor u didaskaliji. Ako u naslagama pamćenja koje formira usmena književnost (ovdje čuvena balada), nije ostala riječi duvak, privedena je u pamćenje jezikom likova, ne jezikom autora.

Kad se lagahno otkri zbog darivanja djece, kako stoji u autorskoj didaskaliji, skida i svoju 'zaštitu'. U jeziku II Svata: snimila je duvak (snimila 'skinula'). Nezaštićenu, Hasan-aga je gleda i izgovara posljednje dramske riječi tragedije. Simbolično 'skrivanje' i 'otkrivanje' - ključna su mjesta drame i one granice koje se u boli uspostave (skrivanje velom, predugačkim duvakom), i u boli otklone (skidanje vela, duvaka).

Turcizam duvak zasigurno je manje poznata (s aspekta čitatelja). Ima značenje blisko riječi veo, pa se zato riječi uzimaju kao sinonimne: 'pokrivalo' su za žene. No duvak je suženog značenja kao poseban 'mladenski' veo, veo mlade! Vjerovatno je i posebno lijep - kao dio svečane odjeće u važnom činu. U drami je neuobičajeno 'dug'. Takav, kako zapravo u dramskom tekstu funkcioniraju?

Nakon što na svatovskom putu komentira ono što čitalac nije mogao vidjeti ni znati:

Umalo mlada ne izgubi duvak, prije vakta i takata! (Hasanaginica, 276)

u drugoj replici Svat proširuje priču:

...Duvak joj je predugačak. Poručila je taki duvak od mladoženje da ne vidi kako će do njega doći (Hasanaginica, 277).

Ako nije ranije, čitalac je tu saznao da duvak pripada Hasanaginici, da je predugačak, da ga je tražila od mladoženje, da ga nosi da ne bi vidjela svoju djecu ili djeca nju. Nepoznanice za čitatelja nema: Isaković je

\footnotetext{
${ }^{39} \mathrm{U}$ usmenoj knj. česte su fraze u obraćanju očni vide a zenico moja - česta je sintagma i u drami; u narodnoj lirskoj pjesmi često se govori o sudbonosnom pogledu i 'gledanju' (npr. Sejdefa, bolesna, poziva svoje prvo gladnje; sevdalija poručuje: gledaj me, nagledaj me se).
} 
odabrao postupak (preko posmatrača - dvojice svata) da 'svu svadbenu dramu' nesretne žene kaže na najkraći način i kroz dijalog sporednih likova, svjedoka tragične scene. Riječ veo, u didaskaliji dovedena u sinonimnu vezu s duvakom, u funkciji je rječničkog tumača turcizma duvak, koja je u posjedu jezika dvojice sporednijih likova (čiji je jezik okarakteriziran kao razgovorni idiom, up. tako, vakat $i$ takat, prid, tri sahata, lahko, dobro izać, baška, take, vake, vallahi, nejma). I sve su nedoumice, ako ih je čitalac imao, otklonjene: duvak je veo. Nije riječ samo o stilskoj vrijednosti leksičke raznovrsnosti i bogatstvu Isakovićeve drame, ni pojačanju podtekstne veze drame i čuvene balade. Možda se ovakvi postupci u leksici mogu tumačiti kao način stvaranja vlastitog referenta (tekstom) u preplitanju pozicije prošlog vremena (kod/jezik junaka prošlog vremena) i pozicije kasnijih vremena (kod/jezik potonjeg čitaoca/gledatelja). Veo, duvak - ključne su riječi, skoro lajtmotivske - za ove scene, a i narednih, do kraja. Za njih je vezana, kako smo vidjeli, i ona neočekivana nagla promjena $\mathrm{u}$ dramskoj napetosti, iza koje slijedi - u tragediji - nužno tragično razrješenje.

No, kao što je neko napisao jednom: kruna u Kornelijevoj tragediji nije tek zlatni predmet s ukrasima od dragog kamenja već u prvom redu predstavlja kraljevstvo ili kralja - kako ga vidi Kornel i njegova publika (up. Iberfeld, 1982:29) - tako ni veo i duvak nisu tek ženski odjevni predmet. Oni su ukras žene, zaštita njenih emocija i integriteta, kako ih ovdje vidi Isaković. Tekst sebi stvara vlastiti referent - uz onaj koji dobija/ima u kodu (jeziku). Tu je prostor u kojem Isakoviće različitim postupcima modelira i gradi svoje originalno djelo 'nastalo iz ljubavi prema usmenoj baladi' narodnog genija, kako sam piše u dramskom 'prologu'.

\section{ZAKLJUČNO}

Najveći doprinos književnika Alije Isaković bosnistici zasigurno i jeste, u području leksikografskog rada, njegov Rječnik (s 13500 riječi natuknica ili 24000 ekscerpiranih uzoraka, up. Rječnik, 487). ${ }^{40}$ Rječnik je koncipiran na način rječnika: njegovo jezgro (izbor i popis natuknica

\footnotetext{
${ }^{40}$ O Rječniku, kao čuvaru identiteta bosanskoga jezika, pisala sam 1993. u časopisu Behar (Zagreb), nakon što je bosanski jezik reafirmirao svoje staro ime.
} 
te tumačenje značenja) ispisani su iz pozicije autora, a citirani dijelovi uz pojedine natuknice 'tuđi' su (izvori).

Dio Rječnika kojemu pripada popis od 13.500 riječi, uokviruju dva Isakovićeva teksta. Jedan je otvarački (studija Slovo o bosanskom jeziku), drugi 'zatvarački' (pledoaje Post factum), koji govori o samom izboru karaketristične leksike u bosanskome jeziku. To su riječi, kao što smo vidjeli, književno sumnjivih riječi, značenjski $i$ normativno ambivalentnih, jezičkom isključivošću osakaćenih, nepriznavanjem osramoćenih; riječi (s više razloga) protjeranih $u$ arhaizme, $u$ provincijalizme, u tudice, riječi $s$ indignacijom odbačenih, što ne priliči nikojem $i$ ničijem pravopisu, (Isaković, 1993: 483). Isaković karakteristične lekseme opisuje kao: sumnjive, osakaćene i osramoćene (odnos prema njima), a ambivalentne, arhaične, provincijske, tuđe (s aspekta tada važeće standardnojezičke norme - rječničke, gramatičke i pravopisne). Nastoji svojim rječnikom, kako kaže, tim riječima vrati njihovu književnu čast i javno uvažavanje (Isto, 483). U Post factumu govori šta su sve te riječi, karakteristične u bosanskome jeziku, sačuvale o bosanskome jeziku. Napominje da svrha njegovog Rječnika nije da vadi iz pepela neke arhaizme, samo zato što su dio bosanske muslimanske/Bošnjačke tradicije, (Isto, 486). U okvirnim dijelovima svoga Rječnika govori o riječima i oblicima koji egzistiraju u našem jeziku i pisanju protivno pravopisnim normama od prve do današnje /.../, kako su pisali naši bosanski preci. (Isto, 486)

Isakovićev rječnički postupak potvrđuje da su u Bosni, utočištu naroda, vjera i kultura, Bosanci svoj govor bogatili i pisali pismima svjetskih civilizacija, u samoj molitvi nosili individualizam, a kolektiv gradili na temelju zadanih prostora, zakona, konvencija i znanja; u svojim knjigama nisu uljepšavali sliku o sebi. Bosanskohercegovačka multikulturalnost vremenska je i prostorna kategorija, kao i njen bosanski jezik. U savremenim je Bošnjacima sadržaj pažljivo ugrađivan nježnom i grubom rukom povijesti. Njihova je materijalna i duhovna kultura markantna i rijetka, davno prepoznata u romantičarskoj Evropi. $\mathrm{S}$ dragocjenim iskustvom komunikacije s vremenom koje dolazi, bez straha od nepoznatog jer je na mjestu susreta civilizacija, Bosna svoj jezik sačuvala u usmenoj i pisanoj kulturi. Isaković je minuciozno i strpljivo cijelo desetljeće sabirao, bilježio i objavio ono što je zanemarivano i nepravedno potiskivano. Drama nastala $\mathrm{u}$ jednom 
historijskom trenutku, Hasanaginica govori o jednom historijskom vremenu. Mi i ne možemo znati, i da hoćemo, kako se tada govorilo, u vrijeme u koje je Isaković smjestio svoju dramu. Imamo samo ono što je sačuvano u tekstovima. Jedan je od njih balada, ali su tu i uspavanka, i epska poezija, i alhamijado književnost i brojni drugi tekstovi (s ovog aspekta: metajezički). Na raspolaganju stoji i fond zanemarene i zapostavljene leksike smještane u depandans, rezervu iz koje se crpi riječ - kad je potrebna. To znači: i karakteristične leksike u bosanskome jeziku. $^{41}$

\section{Izvori}

1. Isaković, A. (1995) Drame (To, Generalijum, Hasanaginica), Preporod, Sarajevo

2. Isaković, A. (1993) Rječnik karakteristične leksike u bosanskome jeziku, Bambi, Wuppertal

\section{Literatura}

3. Bratinić, M. (1991) Rječnik i kultura, SOL, Zagreb

4. Brozović D. (1969) Kritika, Zagreb

5. Dizdar, M. (1971) Stari bosanski tekstovi, Svjetlost, Sarajevo

6. Dizdar, M. (1970) Marginalije o jeziku i oko jezika, u: Život, Sarajevo

7. Hadžiefendić, R. (1993) Jezik savršenog kontinuiteta (Alija Isaković: Rječnik karakteristične leksike bosanskoga jezika, Svjetlost, Sarajevo, 1992), Behar, Zagreb, 1993, str. 24-25

8. Hadžiefendić, R. (1987) Glagoli govorenja u autorskim remarkama i upravni govor, Književni jezik, XVI/3-4, Sarajevo

9. Hadžiefendić-Parić, R. (2016) Lingvostilistički zapisi, Preporod, Zagreb

10. Ibersfeld, A. (1982) Čitanje pozorišta, Vuk Karadžić, Beograd

11. Kapetanović, A. (2005) Historizmi i semantičke promjene, Rasprave Instituta Institut za hrvatski, 32, Institut za hrvatski jezik i jezikoslovlje, Zagreb

\footnotetext{
${ }^{41} \mathrm{Na}$ kraju stoji odlomak jednog ranijeg izlaganja na Tribini Sulejman Mašović Isl. centru u Zagrebu.
} 
12. Lalević, M. S., (1974) Sinonimi i srodne reči u srpskohrvatskom jeziku, Leksikoni sveznaje, Leksikografski zavod Sveznaje, Beograd

13. Lovrenović, I. (1991) Svijet u prezentu, predg. u: Alija Isaković, Taj čovjek, Pobuna materije, Svjetlost, Sarajevo

14. Palić, I., Šehović, A., Halilović, S. (2010) Rječnik bosanskoga jezika, izd. Filozofski fakultet, Sarajevo

15. Peti, M. (1995) Jezikom o jeziku, Stavljanja i suprotstavljanja, Zagreb, 103-120

16. Sinanović, E. (1996) Bošnjačka drama, Cambi, Lovran

17. Šehović, A. (2012) Jezik u bosanskohercegovačkim dramama, Institut za jezik u Sarajevu

18. Škaljić, A. (1989) Turcizmi u srpskohrvatskom jeziku, Svjetlost, Sarajevo

19. Trhulj, S. (2011) Rječnik moje majke, Prilog leksičkom blagu bosanskoga jezika, treće, dopunjeno izdanje, Dobra knjiga, Sarajevo

20. Uskufi, M. H. (2012), Bosansko-turski rječnik, Izd. V.B.Z. d.o.o. Sarajevo, Tuzla

21. Žic-Fuks, M. (1989) Osnovna obilježja oslovljavanja u Zagrebu, SOL, 7/1, 27-38.

22. Žic-Fuchs, M. (1991) Znanje o jeziku i znanje o svijetu, SOL, Zagreb. 


\title{
ISAKOVIĆ'S HASANAGINICA AND HIS DICTIONARY OF CHARACTERISTIC LEXICON IN THE BOSNIAN LANGUAGE
}

\author{
PhD Remzija Hadžiefendić-Parić, Islamic Faculty of Pedagogy \\ University of Bihać \\ E-mail: remzija.hadziefendic.paric@zg.t-com.hr \\ It should finally meet a long time ago \\ with a runaway heart(M.Dizdar)
}

\section{SUMMARY}

The paper focuses on the lexical composition of Isakovic's drama Hasanaginica (1982) with regard to extraction procedures and the interpretation of vocabulary in his Dictionary of Characteristic Lexicon in Bosnian (1991). The aim is to determine the relation between the words in the drama Hasanaginica and the lexemes included in the Dictionary - with the starting assumption that there is a certain coincidence in their choice, form and meaning, without losing sight that they are two completely different types of texts, verse and genre. two styles - literary (drama, tragedy) and applied scientific (vocabulary, monolingual), which entails a number of important, contradictory differences in terms of vocabulary and its functioning in the text, though both language and drama are 'meta-languages' '(cf. Peti, 1995: 103), one in preasentia (drama), the other in absentia (dictionary). The analysis therefore assumes that drama and vocabulary consist of different components structurally (in terms of place in the text), formal (in terms of writing), functional (in terms of roles in the 'second-level model system' and in the lexicographic work) and lingual (in terms of values and effects). To the best of my knowledge, there has been no scientific interest or research on this topic so far. In the paper, I have focused only on certain words from the drama through which I can trace and ultimately identify the essential contours of the relationship between drama and the Dictionary from the aspect selected in this paper.

Keywords: ballad, Hasanaginica, drama, dictionary, Alija Isaković, Bosnian, Bosnia. 


$$
\begin{aligned}
& \text { الأستاذ الدكتور سيدة رمزية حاجيئفنديتش - باريتش } \\
& \text { جامعة بيهاتش } \\
& \text { كلية التربية الإسلامية }
\end{aligned}
$$

E-mail: remzija.hadziefendic.paric@zg.t-com.hr

\section{"هاساناغينيتسا" لمؤلفها إيساكوفيتش وقاموسه لألفاظ المميزة في اللغة البوسنية}

$$
\text { "ينبغي أن يُجتمع أخيرا مع قلب هارب منذ وقت طويل" (م. دزدار) }
$$

\section{الملخص}

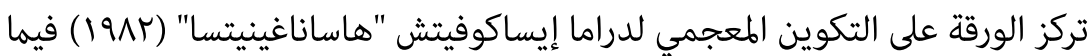

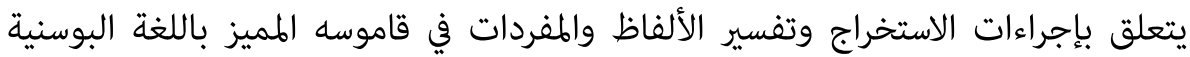

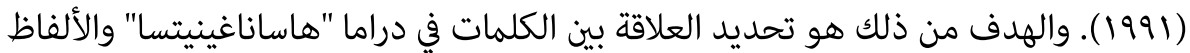

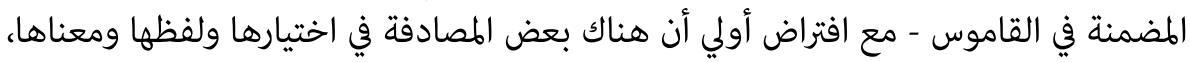

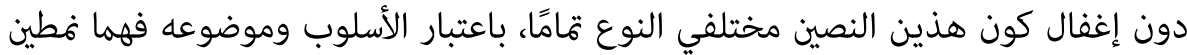

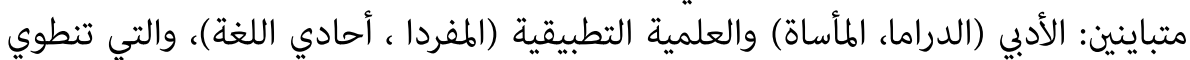

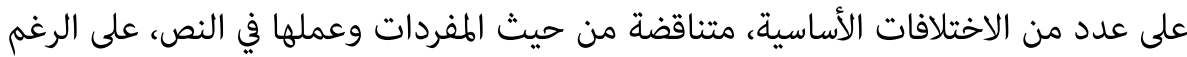

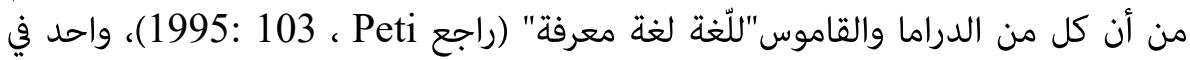
دراما (مسرحية)، والآخر معجم (قاموس).

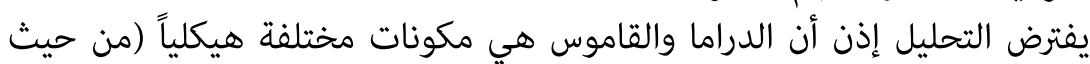

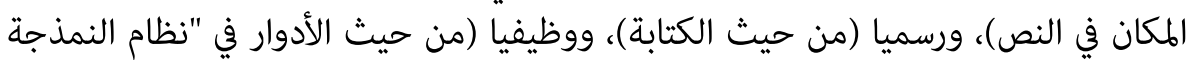

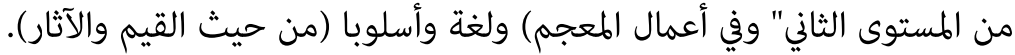

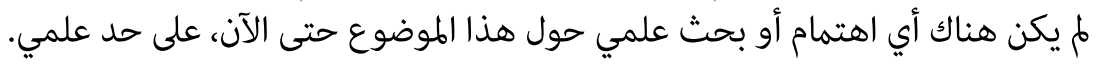

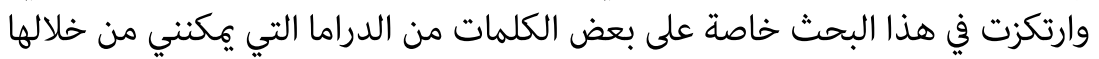

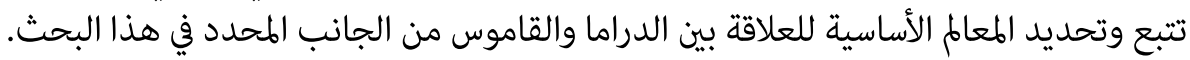

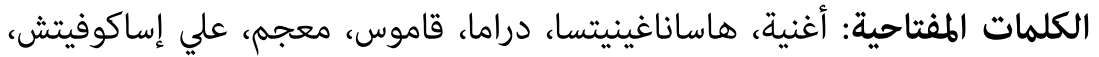
اللغة البوسنية، علم اللغة البوسنية. 